\title{
CONFRONTING RECENT HISTORY: FORCED MOBILIZATION IN SERBIA DURING THE WAR IN CROATIA 1991-1995
}

\author{
SRĐAn MLADENOV JovanOVIĆ
}

\begin{abstract}
However much interest the Yugoslav conflicts of the nineties seem to have sparked within the broader academic community, some relevant topics are still found to be missing or underresearched. The forced mobilization during the Milošević regime that culled men of almost all age in order for them to fight for their country is one of them. With the recently published Untold stories of the victims of the forced mobilization, some new light has been shed on the cullings of the 1990s. This article explores those stories, including recently emerged transcripts from the governmental sessions discussing them, and puts them through a historical lens.
\end{abstract}

Author: Srđan Mladenov Jovanović, Nankai University, China, smjovanovic@nankai.edu.cn, ORCID ID: https://orcid.org/0000-0003-2612-4733

Keywords: forced mobilization, culling, Yugoslav wars, Željko Ražnatović Arkan

Balcanica Posnaniensia. Acta et studia, XXVII, Poznań 2020, Wydawnictwo Wydziału Historii UAM, pp. 167180, ISBN 978-83-66355-54-5, ISSN 0239-4278. English text with summary in English.

doi.org/10.14746/bp.2020.27.11

The Yugoslav wars of the nineties have been the core of scholarly attention ever since the wars started, producing an impressive amount of scholarship from vast array of disciplines ${ }^{1}$. These works have produced an impressive collection of reports, theories,

${ }^{1}$ For just a general overview: D. Anderson, The Collapse of Yugoslavia: background and summary, Department of the Parliamentary Library, 1995; N. Andjelic, The rise and fall of Yugoslavia: politics and football in the service of the nation, „Südosteuropa. Zeitschrift für Politik und Gesellschaft” 2014, vol. 2, p. 99-125; I. Banac, The National question in Yugoslavia: origins, history, politics, Ithaka 1984; S. Biserko, The Dissolution of Yugoslavia: roots of the conflict. Humanity in action, 2013, https://www. humanityinaction.org/knowledgebase/360-the-dissolution-of-yugoslavia-roots-of-the-conflict [access: 30.09.2020]; R. Blackburn, The Break-up of Yugoslavia and the fate of Bosnia, "New Left Review" 1993, no. 199, p. 100; M. Bookman, War and peace: the divergent breakups of Yugoslavia and Czechoslovakia, "Journal of Peace Research" 1994, vol. 31, no. 2, p. 175-87; G. Bowman, Xenophobia, fantasy and the nation: The logic of ethnic violence in former Yugoslavia, in: Anthropology of Europe: Identity and boundaries in conflict, eds. V. Goddard, J. Llobera, R. Shore, Oxford 1994, p. 43-171; D. Chandler, Western intervention and the disintegration of Yugoslavia, 1989-1999, in: Degraded capability: the media and the Kosovo crisis, London 2000, p. 19-30; B. Denich, Dismembering Yugoslavia: nationalist ideologies and the symbolic revival of genocide, „American Ethnologist” 1994, no. 21/2, p. 367-390; D. Djokić, J. Ker- 
analyses, and overviews. Nevertheless, since the bloodshed ended, scholarly interest in the former Yugoslav region has dwindled to almost a halt. Even though the prolific amount of academic works have tackled a truly vast array of issues, the issues that need confronting are still aplenty. From the point of view of history the scholarly production can even be said to be lacking.

This is why this will be an account of the forced mobilizations that have taken place in several locations in Serbia during the troublesome nineties, as history, as a discipline, still has not dealt with these issues. Having in mind that the progeny of Željko Ražnatović Arkan, the warmonger who was in charge of many of forced mobilizations and torture, his son and daughter, including his widow, Svetalana Ražnatović Ceca, currently have an important place in public discourse. What is more, most often shown in a positive light, these issues are in urgent need of addressing. Furthermore, detailed reports of the forced mobilizations have only recently been published, such as the 2019 Fond za humanitarno pravo report on forced mobilizations ${ }^{2}$, or the on-

Lindsay, New perspectives on Yugoslavia: key issues and controversies, Abingdon 2010; N. Dobrković Yugoslavia and Macedonia in the years 1991-1996: from brotherhood to neighbourhood, in: The new Macedonian question, 1999, p. 79-95; G. Duijzings, Ethnic unmixing under the aegis of the West: a transnational approach to the breakup of Yugoslavia, „Bulletin of the Royal Institute for Inter-Faith Studies” 2003, vol. 5, no. 2, p. 1-16; Z. Golubović, Social change in 1990's and social character: The case of Yugoslavia, „Sociologija” 1995, vol. 37, no. 4, p. 441-453; R. Hayden, Imagined communities and real victims: self-determination and ethnic cleansing in Yugoslavia, „American Ethnologist” 1996, vol. 23, no. 4, p. 783-801; K. Hudson, Breaking the South Slav dream: the rise and fall of Yugoslavia, London 2003; S. Jovanović, The Creation and breakup of Yugoslavia and Czechoslovakia: developing polypeitharchic history, Belgrade 2017; M. Knezevic, Reporting rights? A look at threats to journalism in the former Yugoslavia since the Balkans wars, „Index on Censorship” 2015, vol. 44, no. 3, p. 52-55; E. Kohn, Rape as a weapon of war: women's human rights during the dissolution of Yugoslavia, „Golden Gate UL Rev." 1994, no. 24, p. 199; R. Lindsey, Rose, From atrocity to data: historiographies of rape in former Yugoslavia and the gendering of genocide, „Patterns of Prejudice” 2002, vol. 36, no. 4, p. 59-78; J. LópezBarajas Aguilar, Y llegó la barbarie. Nacionalismo y juegos de poder en la destrucción de Yugoslavia, "Cuadernos de Historia Contemporánea" 2016, no. 38, p. 474-475; S. Lucarelli, Europe and the breakup of Yugoslavia: a political failure in search of a scholarly explanation, Leiden 2000; B. Magaš, The destruction of Yugoslavia: tracking the break-up 1980-92, London-New York 1993; M. Mandelbaum, A perfect failure: NATO's war against Yugoslavia, "Foreign Affairs" 1999, vol. 2-8; G. Massey, R. Hodson, D. Sekulić, Ethnic enclaves and intolerance: The case of Yugoslavia, "Social Forces" 1999, vol. 78, no. 2, p. 669-693; M. Mihajlov, Can Yugoslavia survive?, "Journal of democracy" 1991, vol. 2, no. 2, p. 7991; N. Naimark, H. Case, Yugoslavia and its historians: understanding the Balkan wars of the 1990s, Stanford 2003; A. Oberschall, The manipulation of ethnicity: from ethnic cooperation to violence and war in Yugoslavia, „Ethnic and racial studies” 2000, vol. 23, no. 6, p. 982-1001; B. Orel, The Theatre exchange between Slovenia and the republics of former Yugoslavia in the 1990s, in: Theatre in the Context of the Yugoslav Wars, New York 2018, p. 227-242; A. Pavković, The fragmentation of Yugoslavia: nationalism and war in the Balkans, New York 2000; R. Perks, A. Thomson, The oral history reader, Abingdon 2015; G. Powers, Religion, conflict and prospects for reconciliation in Bosnia, Croatia and Yugoslavia, „Journal of International Affairs” 1996, vol. 50, p. 221-252; S. Ramet, Thinking about Yugoslavia: scholarly debates about the Yugoslav breakup and the wars in Bosnia and Kosovo, Cambridge 2005; idem, V. Pavlakovic, Serbia since 1989: politics and society under Milosevic and after, Washington 2007, http:// public.eblib.com/choice/publicfullrecord.aspx? $\mathrm{p}=3444386$ [access: 30.09 .2020 ].

2 J. Kolarić, Dosije: prisilna mobilizacija izbeglica, Beograd 2019. 
line repository of victims of forced mobilizations, including their own recollection of the events, Neispričane priče ${ }^{3}$, as well as the Rat $u$ Srbiji repository ${ }^{4}$, these are primary sources that need to be included in scholarly musings and recollections of the nineties. Much of the information was retrieved by the Fund for Humanitarian Right's collections of victim's stories, reviving the concept somewhat forgotten in historical research - oral history ${ }^{5}$. The current literature on forced mobilizations within scholarly production is stunningly rare, and most commonly takes the form of psychological analyses and assessments of the victims ${ }^{6}$, with some additional works touching on the subject ${ }^{7}$.

\section{THE CONTEXT}

During the military conflicts in Croatia (1991-1995) and Bosnia (1992-1995), several hundreds of thousands of Serb refugees fled to Serbia, especially after the military campaigns Flash and Storm (Bljesak and Oluja, respectively) ${ }^{8}$, where they were met with hostility instead of compassion. Flash and Storm were Croatian military advancements whose aim was the ethnic cleansing of Serbs; they were rather successful, and are even today celebrated in Croatia. According to the FHP report, the Operation Flash was:

an action by the Croatian police and army, conducted at the beginning of May 1995 with the goal of returning Western Slavonia under the control of the Croatian army ... the Operation Flash resulted in the ethnic cleansing of the area of Western Slavonia, where around 1000 Serbs were left out of 13,000, while Operation Storm was an action conducted by the Croatian army and police in August 1995, by which Croatian regained control of the territories controlled by the forces of the Republic of Srpska Krajina from 1991 to 1995. During and after this operation, systematic and well-spread crimes were committed against the civilian populace of Serb nationality and their property? 2020].

${ }^{3}$ Neispričane priče in: http://www.neispricaneprice.com/prica/ukradena-sloboda/ [access: 27.11.

${ }^{4}$ YIHR (Youth Initiative for Human Rights), Rat u Srbiji, 2020.

${ }^{5}$ On oral history see: R. Perks, A. Thomson, The oral history reader, Abingdon 2015; L. Abrams, Oral history theory, Abingdon 2016.

${ }^{6}$ J. Cvetković, B. Đorđević, S. Špeh, Grupna psihoterapija pacijenata sa iskustvom torture i prisilne mobilizacije, in: Posledice prinudne mobilizacije izbeglica 1995. godine, eds. G. Opačić, V. Jović, B. Radović, G. Knežević, Beograd 2006, p. 131; V. Jović, Psihoanalitički osvrt na pitanja kompenzacije prisilno mobilisanih izbeglica, in. ibidem, p. 105-130; M. Mitić, S. Vuković, Psihološki profil prisilno mobilisanih, in: ibidem, p. 79; B. Radović, ,Oni” su ih htjeli, a ,on” nije: o kontekstu, organizaciji i sprovođenju prinudne mobilizacije izbeglica u Srbiji 1995. godine, in: ibidem, p. 11.

${ }^{7}$ S. Lischer, S. Kenyon, Militarized refugee populations: humanitarian challenges in the former Yugoslavia, in: The Rosemarie Rogers Working Paper Series, 1999, no. 5.

8 J. Kolarić, op. cit., p. 7.

${ }^{9}$ Ibidem, p. 9. 
The result of the numerous war crimes committed by Croatian forces, based on the UN Security Council Resolution 827, were tackled via prosecution by the ICTY, concentrating on prosecuting Markač, Gotovina, and Čermak for the participation in a JCE (Joint Criminal Enterprise). The Croat forces rampage did not end with the attack on the ethnic Other, but, according to some reports, Croat forces were responsible for $90 \%$ of the looting of UN property as well ${ }^{10}$.

There was a „mobilization crisis” in the Fall of 1991, when the official calls to mobilization did not go beyond $50 \%$ in Serbia as a whole, and $15 \%$ in Belgrade ${ }^{11}$. In other words, men did not want to fight a pointless war; the extremely low response in Belgrade is congruent with the fact that Belgrade hosted a more educated population than the rest of (rural) Serbia, and awareness of the utter futility of the conflict would be more common in Serbia's urban spaces. Having in mind the extremely low mobilization response, for refugee men, militarization took the form of forced conscription and did not directly affect the provision of assistance to other refugees ${ }^{12}$. In order to see the subject from an objective lens, it would be wise to notice that Croatia behaved similarly, but with Bosnian refugees, after the Croat-Bosnian military alliance was formed, and then collapsed, as in late 1992 and 1993, Croatian officials forcibly repatriated draft-age Bosnian males to fight in the Bosnian army as part of a friendship agreement between the two states. When the alliance between the Muslims and Croats collapsed in 1993, Croatia forcibly repatriated Bosnian men to the Bosnian Croat prison camps rather than to the Bosnian Army ${ }^{13}$.

During and after operations Flash and Storm, around half a million of people of Serbian ethnic background and/or identification were displaced, and consequently arrived in Serbia, between 1991 and 1995. Not only were they not met with compassion and much required assistance, but a significant number of males were soon forcefully drafted into war by the military and police institutions of the Republic of Serbia, with the assistance of paramilitary formations, the most infamous of which were Arkan's SDG ${ }^{14}$.

On 9 December, the meeting of the Supreme Defence Council (VSO, Vrhovni savet odbrane) was held, during which Slobodan Milošević, president of Serbia and Montenegro, asked for the cessation of hospitality to conscripts who should by any means be needed to be returned to the territory to defend their homes ${ }^{15}$. Since the

${ }^{10}$ W. Schabas, The UN international criminal tribunals: the former Yugoslavia, Rwanda and Sierra Leone, Cambridge 2006, p. 3-4.

${ }^{11}$ O. Backović, M. Vasić, A, Vasović, Ko to rado ide u vojnike - mobilizacijska kriza - analitički pregled medijskog izveštavanja, in: Rat u Hrvatskoj i Bosni i Hercegovini 1991-1995, eds. B. Magaš,

I. Žanić, Zagreb-Sarajevo 1999, p. 353-368.

12 S. Lischer, S. Kenyon, Militarized refugee populations, p. 6.

13 Ibidem, p. 6.

14 J. Kolarić, op. cit., p. 9.

15 Proceedings of the 6th session of the VSO, 09.12.1992, p. 20, http://sense-agency.com/upload/ documents/stenografic_records/BHS/6._Sednica_VSO_9.12.1992.pdf [access: 30.07.2020]. 
Chief of the General Staff of the Army, Momčilo Perišić, from September 1993, listed the collaboration with the Republic of Srpska Krajina as a regular point of order, it was a matter of time before, on October 19, 1993, the Chief of the General Staff of the Army of the Republic of Srpska of Bosnia and Herzegovina, Ratko Mladić, proposed that one of the points of order should be the return of ,escaped conscripts" to the Republic of Srpska ${ }^{16}$. The transcript of the 16th session of the VSO (25.12.1993) records Slobodan Milošević saying the following:

For 19,765 recruits, military-territorial divisions should draft them, so that they should be summoned ... to form a mobilization center in Zvornik. They should be taken away, since they are deserters, to the mobilization center and get directed to serve in the Army of the Republic of Srpska. This is a whole corpus of military deserters who condone criminal activity in Yugoslavia, while evading protecting their land over there ${ }^{17}$.

Note that there was no proof of any criminal activity of the refugees bereft of their homes and possessions in play; Milošević's statement was declarative. Already on the 17 th session of the VSO, Momir Bulatović spoke that the mobilizations were conducted with the help of the police ${ }^{18}$. Transcripts from the VSO sessions have shown uniformity in the sense that the forced mobilization was consistently conducted under the cover of ,assisting" RSK, which was in fact treated as if it were a part of the so-called Greater Serbia, and a reality. The only ,issues" that the VSO attendees had were how to formally and bureaucratically conduct them. Torture camps were referred to as educational centers, while those who would refuse were deemed in need of ,pressure”. The Minister of Defense, Pavle Bulatović, was in charge of coordinating forced mobilizations ${ }^{19}$.

It started by young men getting a letter with the inscription Your fatherland calls you (Otadžbina te zove) ${ }^{20}$, but it quickly devolved into mass kidnappings. Practice followed the prearranged rather soon afterwards, as already in 1993, OSCE reported roaming armed gangs in Vojvodina who were collecting refugees, loading them in trucks, and shipping them off to the front. Tadeusz Mazowiecki, special reporter to the United Nations Human Rights Commission, in his November 1993 report, mentions a group of 500 Serbs from Bosnia that have fled their homes have now been culled for males at the Sremska Mitrovica refugee center, and sent to the front ${ }^{21}$. Mass forced re-

16 Common meeting organizing between GŠ VJ and GŠ VRS at 15.10.1993, no. P05105, Mladić.

17 Transcript of the 16th session of the VSO (25.12.1993): J. Kolarić, op. cit.

18 17th session, in: ibidem.

19 See: Zapisnik sa 17. sednice VSO od 10. januara 1994. godine, str. 37, available at https://www.sen se-agency.com/ upload/documents/stenografic_records/BHS/17._Sednica_VSO_10.1.1994.pdf [access: 30.07.2020]; M. Milošević et al., Ubistvo ministra vojnog, "Vreme", 12.02.2000, https://www.vreme. com/arhiva_html/475/03.html [access: 27.11.2020].

${ }^{20}$ M. Lučić Čavić, Milica, Pregled štampe, 31.01.1994, http://www.aimpress.ch/dyn/pubs/archive/ data/199401/40131-003-pubs-beo.htm [access: 27.11.2020].

21 J. Kolarić, op. cit., p. 15. 
cruitment was seen already in 1994, when around 3000 refugees were shipped over to the military and police branches of the Republic of Srpska via a collective effort of the Military police and the Ministry of Internal Affairs of the Republic of Serbia ${ }^{22}$.

Forced culling continued unabashed in 1995, in the evening of June 11. Refugees were now culled with local citizens as well, including children that have just turned 18 , as well as males who have been granted leave from service due to physical or mental incapability. In other words, by June 1995, every male person was potential "fresh meat for the grinder". Even some national minorities were now included ${ }^{23}$. They were designated as criminals, as Radović wrote, and consequently hunted like criminals ${ }^{24}$. The „Naša borba" daily, at the time one of the exceedingly rare free media, wrote that people were hunted in trams, buses, cafes, night clubs, as well as graduation ceremonies $^{25}$. Even student dorms were raided for the culling ${ }^{26}$. Commonly, the culling was conducted in the witching hour, around three, four o'clock in the morning, when the victim was ambushed, often having been given but 15 minutes to gather the bare necessities ${ }^{27}$. The whole operation looked more like a criminal kidnapping of massive proportions than any normal mobilization ${ }^{28}$. The Milošević-led government denied that any forced mobilization was going on at all. In June 1995, the Ministry of Internal Affairs announced that the people being culled were not citizens of our country, they do not have residence or the status of refugee, they were additionally painting the culled as being involved in criminal acts, criminal offenses, disturbing citizens, and other misdemeanors ${ }^{29}$.

After Operation Storm, in June 1995, close to 200000 refugees arrived to Serbia from Croatia. Forced culling increased. This is when the infamous paramilitary SDG (Srpska dobrovoljačka garda; Serbian Volunteer Guard), led by Željko Ražnatović Arkan, came into the spotlight. Their ,educational center” in Erdut was under Arkan's command, where refugees who were culled were humiliated and tortured (shipping to Erdut happened only in the August mobilization period $\left.{ }^{30}\right)$ :

22 Ibidem, p. 16.

23 B. Radović, ,, Oni” su ih htjeli, a „,on” nije: o kontekstu, organizaciji i sprovođenju prinudne mobilizacije izbeglica u Srbiji 1995. godine, in: Posledice, p. 11.

${ }^{24}$ Ibidem, p. 23.

${ }^{25}$ Mobilizacija u Srbiji između politike i bezakonja: lov na topovsko meso, „Naša borba”, 2425.06.1995, p. V; Racija u beogradskom noćnom klubu „Havana”: upad u „raj za Bosance”, „Naša borba“, 27.06.1995, p. 2; Lov na ljude na novosadski način: e, sad neću ni kako „oću“, „Naša borba”, 29.06.1995, p. 13.

${ }^{26}$ Mobilizacija krajišnika u Srbiji se nastavlja: Milicija ‘čě̌lja’ Studentski grad, „Naša borba”, 15.06.1995.

${ }^{27}$ F. Švarm, Hajka na Krajišnike, 18.06.1995, http://www.aimpress.ch/dyn/pubs/archive/data /199506/50618-001-pubs-beo.htm [access: 27.11.2020].

28 B. Radović, ,, Oni”, su ih htjeli, p. 24.

${ }^{29}$ Kontrola, a ne mobilizacija, ,Večernje novosti”, 25.06.1995.

30 B. Radović, ,,Oni”' su ih htjeli, p. 31. 
every morning in the camp began with the intonation of the anthem „God of Justice”, the raising of the flag, and the speech by Željko Ražnatović, after that, the refugees had to perform hard physical exercises. Those who could not keep up with the pace were punished by having to carry a stone that read Mr. Discipline, some were handcuffed to a tree, some to a dog house, where they had to bark and say that they are „common domestic mutts”31.

The following is an excerpt from a book written by an eyewitness, Miodrag Milojević:

Erdut, dawn. Under the moonlight, people in helmets, with rifles. The railway bridge and the white Danube. The silence is broken by shouting: "Out! Out! Serbian traitors, motherfuckers! We will kill you, we will slaughter you! Run! Run! Run! Get in line!” Batons fly over people's heads from all sides. Eardrums crack from blows, heads are exploding. Thousands of people are still arriving in Erdut by bus. Under the clear sky there are four chairs, next to the chairs, four barbers. The bald haircut takes about half a minute. Raising of the flag is at 7. Arkan addresses: "God help, Serbian volunteers! You are now Serbian volunteers. Your fuckers, you betrayed Krajina!" Thousands of people in line. You can't get out of the machine anywhere. The penalties are terrible. As the flag is raised they choose one, tie him to the pillar and beat him - twenty-five beatings. Everyone has to watch when a man, under batons, twists like a worm. The penalties are various. Binding to poplars along the Danube. They take the man to his waist. They put his arms around the poplar and handcuffed him. The nights along the Danube are cold, full of mosquitoes. Cold water is poured on the naked man $^{32}$.

In the report published by Opačić, Jović, and Knežević3 ${ }^{33}$, around $50 \%$ of the forcefully mobilized refugees reported that they have been subjected to slapping, hitting, kicking, and that they have suffered humiliating comments directed at their family. $45 \%$ reported that they have been subjected to sleep deprivation, while $39 \%$ reported that they have been either deprived of food or of access to the toilet. Threats of death or mutilation have been reported by $35 \%-38 \%, 23 \%$ said that they were forced to stand under heavy weights, and $14 \%$ have been subjected to extreme temperatures. Between $4 \%$ and $10 \%$ reported more cruel forms of torture, such as being tied and stretched for several hours, being thrown from a height, drowned, suffered bastinado, been mutilated (including the breaking of bone), as well as being burned with cigarette butts. Dušan M., one of the victims, reported the following:

We came to Ada on August 18, 1995. We settled in a local school, about ten of us. In the following days, we were well organized, the women cooked and prepared, and we went to Ada for food and other necessities. On the morning of August 24, 1995, members of the Serbian Ministry of the Interior came to the yard of the elementary school in Ada and asked for our documents. Of the men, only I was present at the time. When I gave them my refugee ID, they told me that I had to go with them to some routine interrogation. We went to the police station in Ada, where they detained me for several hours. There were several other men there, who came from Krajina or Bosnia. After those few

${ }^{31}$ See: Prisilne mobilizacije u Srbiji in: https://ratusrbiji.rs/prisilne-mobilizacije-u-srbiji/ [access: 27.11.2020].

${ }^{32}$ Miodrag Veljović cited in: B. Radović, „Oni” su ih htjeli, p. 32.

${ }^{33}$ G. Opačić, V. Jović. G. Knežević, Tortura ili obuka: vrste mučenja u grupi izbeglica prisilno mobilisanih u Srbiji u toku 1995. godine, in: Posledice, p. 66. 
hours, a bus came, and they took us. When we asked where they were taking us, only one of the police officers answered that the order had arrived that we had to return to our positions. We were taken to Erdut, and there they took us to the training center of the Serbian Volunteer Guard. Upon arrival, Željko Ražnatović Arkan was waiting for us, who took some of us out of the line and started shouting at them, and asked why we left Krajina and who would now go to war with the Croats. We spent five days in Erdut, and some of us were severely mistreated and tortured during that period. After five days, I was supposed to be transferred to Bršadin with one unit, but I still ended up in Pačetin, on the first battle line between Croatia and Eastern Slavonia. I was in one mortar unit, and I was operating a $120 \mathrm{~mm}$ mortar. I was soon able to call my family in Ada, in one short phone conversation. I spent three and a half months in Pačetin. On several occasions, I spoke with Goran Hadžić, then president of Eastern Slavonia, who suggested that we inform the families to come and move to Lipovac, a village near Pačetin, to abandoned Croatian houses. After three and a half months, I was released and went to Serbia to look for my family, which I found in Mol, a village in the municipality of $\mathrm{Ada}^{34}$.

\section{Đuro, another victim, reported the following:}

After being arrested and asked a few questions, which referred to the place and time of arrival in Serbia, they sent me to Zrenjanin, from where I was taken by bus, which was full of Serbs from Krajina to Erdut, to the training camp of the Serbian Volunteer Guard. I spent the next eight days there. I will never be able to forget that period, those eight days in Erdut. Upon arrival, I passed through a line of soldiers present, who shot and hit me with their hands. They kept telling me that I was a traitor, and that Krajina had failed because of me and people like me. On the same day, I had a very short haircut, almost bald. Torture continued in the following days. Over 7,000 people were present at the time I was in the camp, from all over the former Krajina. Everyone was scared and tortured. After eight days, I was transferred to Beli Manastir, from where I was immediately transported to Novi Čeminac. There, I and other people who were forcibly mobilized served as a supplement to the army of Eastern Slavonia. The positions of the Croatian army were about 200 meters across the Drava. I spent more than three months there. During that period, we were not allowed to contact our families, nor to go and visit them. They constantly addressed us as traitors, and said that we deserved everything that happened to us. I took care of the family, the daughter who was supposed to continue her education, and I kept thinking about them. After three months, I was returned to Serbia. I lost more than ten pounds during my stay. Even after leaving, I kept thinking about the torture I went through, the shootings, the name-calling, the spitting. I had a hard time getting back into the daily routines of life ${ }^{35}$.

The FHP categorized the culling into several categories: culling from reception facilities, from private homes, from workplaces, on the street, from catering facilities, from dorms, from refugee lines ${ }^{36}$. The victims' accounts, given to the Fund for Humanitarian Right, were consistent.

Several victims reported that officers from the Ministry of Internal Affairs came to the reception facilities with lists of people that they have taken from the Red Cross,

${ }^{34}$ Neispričane priče, Dušan M: http://www.neispricaneprice.com/zrtva/dusan-m-prisilno-mobilisan/ [access: 27.11.2020].

${ }^{35}$ Neispričane priče, Đuro: http://www.neispricaneprice.com/zrtva/duro-prisilno-mobilisan/ [access: 27.11.2020].

${ }^{36}$ J. Kolarić, op. cit. 
which catalogued whom they assisted after the arrival from Croatia ${ }^{37}$. Some have even reported that the people from the Ministry used violent force to take said lists from the members of the Red $\mathrm{Cross}^{38}$. One victim said that a month after he was, with his wife, settled in a reception facility in Vranje, he went to see the dentist, where the police picked him up without allowing him to finish or to report to his wife ${ }^{39}$. Another said that, after he had been culled, he saw a neighbour who was forcefully drafted as well, even though he had been without a hand since childhood ${ }^{40}$. Other people with official documentation proving their status as disabled were culled as well ${ }^{41}$. More were culled even from their newly gained workplaces, as some of the refugees were able to settle down and find employment once they have arrived ${ }^{42}$. They were even culled on the street:

I think it was on 10 September 1995, the Serbian police picked me up when I was coming back from the store. Two officers stopped me and asked for my identification. I had no ID on my person, but I told them that my documentation was nearby in the Šumice motel, but a couple of hundreds of meters away. The policemen did not allow me to fetch my documentation even though I explained to them that I was a refugee. They simply put me in their vehicle and drove me directly to the fire department in Kikinda ${ }^{43}$.

Other victims reported that they had been culled in locations such as restaurants, also without being given the chance to inform their families of the goings on ${ }^{44}$. A large number reported being culled from student dormitories (the youngest of the victims) $)^{45}$. Similarly, victims have reported be-

37 Statement of the wittness J.B. given to The FHP, 06.1998; Statement of the wittness N.K. given to The FHP, 05.1998; Statement of the wittness D.B. given to The FHP, 04.1998; Statement of the wittness N.P. given to The FHP, 05.1997; Statement of the wittness M.K. given to The FHP, 04.1998; Statement of the wittness S.Č. given to The FHP, 02.1998; Statemen of the wittness B.J. given to The FHP, 04.1998; Statement of the wittness R.B. given to The FHP, 06.1997.

38 Statement of the wittness D.L. given to The FHP, 04.1998; Statement of the wittness J.B. given to The FHP, 06.1998; Statement of the wittness J.B. given to The FHP, 06.1998; Statement of the wittness S.Č. given to The FHP, 05.1998, Statement of the wittness M.G. given to The FHP, 05.1998.

39 Statement of the wittness D.G. given to the FHP, 09.1998.

40 Statement of the wittness N.P. given to the FHP, 05.1997.

41 Statement of the wittness D.R. given to the FHP, 05.1997.

42 Statement of the wittness S.B. given to the FHP, 05.1997; Statement of the wittness N.L. given to the FHP, 04.2013; Statement of the wittness M.D. given to the FHP, 01.2016; Statement of the wittness N.L. given to the FHP, 04.2013.

43 Statement of the wittness A.M. given to the FHP, 02.1998.

44 Statement of the wittness B.K. given to the FHP, 06.1997; Statement of the wittness D.G. given to the FHP, 12.1998; Statement of the wittness B.Š. given to the FHP, mart 1998; judgement of the First Municipal Court in Serbia P nr. 2600/00 from 21.06.2004, p. 9; Statement of the wittness B.Š. given to the FHP, 03.1998.

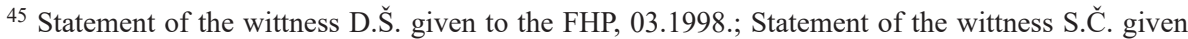
to the FHP, 05.1998; Statement of the wittness M.G. given to the FHP, 05.1998; Statement of Milena Ć., wittness to forced mobilization, Vojvođanski građanski centar, available at: http://www.neispricane price.com/svedok/milena-c-svedokinja-prisilne-mobilizacije/ [access: 27.11.2020]; Statements of Slavka Pecarski and Miloš Stančić, professora of a high-school in Kikinda, available at: http://www.neispricane price.com/svedok/slavka-pecarski-i-milos-stancic-profesori-kikindske-gimnazije [access: 27.11.2020]; 
ing culled straight from the refugee lines whilst coming into the country ${ }^{46}$. One of them reported the following:

I wanted to initially take refuge at my cousin's place in Inđija, but I never arrived. At the entrance to the very place, on 10 August 1995, around 13:00, the car I was driving was stopped by the patrol of the traffic police. The first thing they asked me when they stopped me was the year I was born. When I replied, they asked me to leave the vehicle where my wife was as well. I tried explaining to these people that I do not even have accommodation yet, that I have no idea what happened to the rest of my family, but to no avail. They are shipping me off to the police station ${ }^{47}$.

Others have reported similar stories, with the addition that in some cases, they had been lied to, having been told that they would simply be introduced into some lists, and then released ${ }^{48}$. Often, victims have reported that they were, once culled, relieved of freedom and put into facilities from which they could not get out ${ }^{49}$. They were often even not allowed to drink water, and were followed to the toilet ${ }^{50}$. One reported that he had been handcuffed to the radiator in the police station, like a common criminal ${ }^{51}$. A slew reported that the police had not been interested in those refugees who had a visible disability, or even to see official documentation proving it ${ }^{52}$.

The ,educational centre" in Erdut was where the most disturbing victim recollections took place. Led by Commander Arkan and his paramilitary troops, it was supported by the State Security sector of the Ministry of Internal Affairs. In other words, the state sponsored and supported the paramilitary. The camp in Erdut was under the official responsibility of the General-Mayor Dušan Lončar of the Serbian Army of the Krajina (SVK, Srpska vojska krajine) ${ }^{53}$. This is where utter dehumanization took place. Survivors have reported that they were oft referred to as parcels ${ }^{54}$. One report-

Milicija 'češlja' Studentski grad., „Naša borba”, 15.06.1995; Milicija odvodila mladiće sa maturske večeri, „Naša borba”, 15.06.1995.

${ }^{46}$ Statement of the wittness M.S. given to the FHP, 12.1998; Statement of the wittness M.K. given to the FHP, 12.1998; Statement of the wittness N.K. given to the FHP, 12.1998; Statement of the wittness S.S. given to the FHP, 12.1998; Statement of the wittness M.L. given to the FHP, 06.1997; Statement of the wittness M.G. given to the FHP, 08.1997; Statement of the wittness R.J. given to the FHP, 07.1998.

47 Statement of the wittness M.L. given to the FHP, 06.1997.

48 Statement of the wittness M.G. given to the FHP, 08.1997.

${ }^{49}$ Statement of the wittness B.Đ. given to the FHP, 06.1997; Statement of the wittness S.V. given to the FHP, 04.1997; Statement of the wittness S.B. given to the FHP, 05.1997; Statement of the wittness M.S. given to the FHP, 07.1997; Statement of the wittness R.Š. given to the FHP, 06.1997; Statement of the wittness B.S. given to the FHP, 05.1998; Statement of the wittness D.R. given to the FHP, 02.1998.

${ }^{50}$ Statement of the wittness B.S. given to the FHP, 05.1998; Statement of the wittness B.J. given to the FHP, 03.1998; Statement of the wittness B.Ž. given to the FHP, 11.1998; Statement of the wittness D.D. given to the FHP, 05.1998; Statement of the wittness D.P. given to the FHP, 05.1998.

${ }^{51}$ Statement of the wittness D.Č. given to the FHP, 02.1998.

${ }^{52}$ Statement of the wittness B.K. given to the FHP, 03.1998; Statement of the wittness B.Š. given to the FHP, 11.1998; Statement of the wittness D.R. given to the FHP, 05.1997; Statement of the wittness Đ.G. given to the FHP, 03.1998; Statement of the wittness D.V. given to the FHP, 06.1998.

53 J. Kolarić, op. cit., p. 32.

${ }^{54}$ Statement of the wittness S.M. given to the FHP, 10.1998; Statement of the wittness S.O. given to the FHP, 04.1998; Statement of the wittness D.K. given to the FHP, 10.1998; Statement of the wittness 
ed that a gun was put in his mouth ${ }^{55}$, while others spoke that they were told that "You are only numbers, you are not human, you traitors" $"$. Arkan was reported to have instructed the victims to address him as "Sir Commander" (gospodine komandante), and that he called them traitors and drunkards on a regular basis ${ }^{57}$. The Erdut camp was so horrendous, that other camps used to send victims to it for „re-education”, such as the Center for Training of the Unit for Antiterrorist Action ${ }^{58}$.

The discursive constructions such as referring to a torture camp as to an ,educational centre" is reminiscent of the worst type of authoritarianisms. The forced cullings, the dehumanizing torture, and the utter disregard for human life are what separated the wars of the 1990s from the rest of humanity, and got it under the spotlight globally. What can be seen as extremely problematic is the fact that Arkan's wife (who was also reported to have been in Erdut under uniform), as well as his children, Veljko and Anastasija, are rather popular Serbia-wide, Ceca even being called "the Serbian Mother" in public discourse, a moniker that she herself said was her "favorite" 59 . In the media, she would sometimes be called "Ceca nacionale"60, which could be translated as "national Ceca". The culprits have mostly passed with impunity, with the exception of Slobodan Milošević, who had been sent to the ICTY in the Hague, yet not living to see a verdict against him. Pavle Bulatović was killed in $2010^{61}$, Željko Ražnatović Arkan also got assassinated ${ }^{62}$, while Momir Bulatović not only passed with absolute impunity, but could afterwards be seen writing columns for the press until his recent death ${ }^{6}$.

Đ.B. given to the FHP, 08.1998; Statement of the wittness S.Đ. given to the FHP, 12.1998; Statement of the wittness L.B. given to the FHP, 08.1998.

55 Statement of the wittness M.K. given to the FHP, 05.1998.

${ }^{56}$ Statement of the wittness S.O. given to the FHP, 04.1998.

${ }^{57}$ Statement of the wittness M.D. given to the FHP, 04.1998; Statement of the wittness Ž.B. given to the FHP, 04.1998; Statement of the wittness D.A. given to the FHP, 05.1998; Statement of the wittness R.D. given to the FHP, 04.1998; Statement of the wittness S.S. given to the FHP, 04.1998; Statement of the wittness D. $\breve{C}$. given to the FHP, 04.1998.

${ }^{58}$ Statement of the wittness D.D. given to the FHP, 04.1998; Statement of the wittness D.B. given to the FHP, 04.1998.

${ }^{59}$ Ceca Ražnatović o svojim nadimcima: "Srpska majka” mi je omiljen!, „Svet\&scandal”, 06.02. 2016, https://www.svet.rs/vesti/estrada/ceca-raznatovic-o-svojim-nadimcima-srpska-majka-mi-jeomiljen [access: 27.11.2020].

${ }^{60}$ Ceca nacionale sa Jovanon u ludom provodu! Srpska majka u transu na proslavi Bajrama kod Harisa Džinovića (video), https://www.kurir.rs/stars/3470129/ceca-i-jovana-u-ludom-nocnom-provodupevacica-sve-snimala -a-oni-su-im-pravili-drustvo-lom-video [access: 27.11.2020].

${ }^{61}$ Ministarstvo odbrane: Pavle Bulatović ubijen pre 20 godina a rezultata istrage ni danas nema, „Danas”, 07.02.2020, https://www.danas.rs/drustvo/ministarstvo-odbrane-pavle-bulatovic-ubijen-pre-20godina-a-rezultata-istrage-ni-danas-nema/ [access: 27.11.2020].

${ }^{62}$ N. Rujević, Konačno istina o Arkanovom ubistvu?, „Deutsche Welle”, 10.02.2020, https://www. dw.com/sr/kona\%C4\%8Dno-istina-o-arkanovom-ubistvu/a-52321421 [access: 27.11.2020].

${ }^{63}$ Сваког четвртка на Спутьику: Момир Булатовић - без дистание [Svakog četvrtka na Sputnjiku: Momir Bulatović - bez distance], 08.08.2016, https://rs.sputniknews.com/komentari /201708081112213294-Momir-bulatovic-kolumne-1/ [access: 27.11.2020]. 
Another troublesome issue is the explanation of the monstrosities and dehumanization that was conducted on the victims of the cullings. Opačić, Jović, and Knežević have come to the conclusion that torture was conducted with the sole purpose of showing the complete dominance over the personality and body of the prisoner, and was designed so that it should inflict potentially largest amounts of damage in a psychological manner ${ }^{64}$. This, however, is not within the purview of history as a discipline to deal with. Sadly, beside the one edited volume concentrating on the psychological perspectives of the forcefully culled - published in Serbian, what is more - this topic remains extremely underresearched.

\section{BIBLIOGRAPHY}

Abrams L., Oral history theory, Abingdon 2016.

Anderson D., The collapse of Yugoslavia: Background and summary: Department of the Parliamentary Library, 1995.

Andjelic N., The rise and fall of Yugoslavia: Politics and football in the service of the nation (s), „Südosteuropa. Zeitschrift für Politik und Gesellschaft” 2014, no. 2, p. 99-125.

Backović O., Vasić M., Vasović A., Ko to rado ide u vojnike - mobilizacijska kriza - analitički pregled medijskog izveštavanja, in: Rat u Hrvatskoj i Bosni i Hercegovini 1991-1995, eds. B. Magaš, I. Žanić, Zagreb-Sarajevo 1999, p. 353-368.

Banac I., The national question in Yugoslavia: origins, history, politics, Ithaka 1984.

Biserko S., The Dissolution of Yugoslavia: roots of the conflict. Humanity in action, 2013, https://www. humanityinaction.org/knowledgebase/360-the-dissolution-of-yugoslavia-roots-of-the-conflict [access:30.09.2020].

Blackburn R., The Break-up of Yugoslavia and the fate of Bosnia, „New Left Review” 1993, no. 199, p. 100.

Bookman M., War and peace: The divergent breakups of Yugoslavia and Czechoslovakia, „Journal of Peace Research" 1994, vol. 31, no. 2, p. 175-187.

Bowman G., Xenophobia, fantasy and the nation: The logic of ethnic violence in former Yugoslavia, in: Anthropology of Europe: Identity and boundaries in conflict, eds. V. Goddard, J. Llobera, R. Shore, Oxford 1994, p. 43-171.

Chandler D., Western intervention and the disintegration of Yugoslavia, 1989-1999, in: Degraded capability: the media and the Kosovo crisis, London 2000, p. 19-30.

Cvetković J., Đorđević B., Špeh S., Grupna psihoterapija pacijenata sa iskustvom torture i prisilne mobilizacije, in: Posledice prinudne mobilizacije izbeglica 1995. godine, eds. G. Opačić, V. Jović, B. Radović, G. Knežević, Beograd 2006, p. 131.

Denich B., Dismembering Yugoslavia: nationalist ideologies and the symbolic revival of genocide, „American Ethnologist” 1994, no. 21/2, p. 367-390.

Denich B., Unmaking multiethnicity in Yugoslavia: media and metamorphosis, in: Neighbours at war: anthropological perspectives on Yugoslav ethnicity, culture, and history, eds. J. Halpern, D. Kideckel, 2000, p. 39-55.

Denitch B., Ethnic nationalism: the tragic death of Yugoslavia, Minneapolis 1996.

Djokić D., Ker-Lindsay J., New perspectives on Yugoslavia: key issues and controversies, Abingdon 2010.

${ }^{64}$ G. Opačić, V. Jović, G. Knežević, Tortura ili obuka, p. 73. 
Dobrković N., Yugoslavia and Macedonia in the years 1991-1996: from brotherhood to neighbourhood, in: The new Macedonian question, 1999, p. 79-95.

Duijzings G., Ethnic unmixing under the aegis of the West: a transnational approach to the breakup of Yugoslavia, „Bulletin of the Royal Institute for Inter-Faith Studies” 2003, vol. 5, no. 2, p. 1-16.

Golubović Z., Social change in 1990's and social character: The case of Yugoslavia, „Sociologija” 1995, vol. 37, no. 4, p. 441-453.

Hayden R., Imagined communities and real victims: self-determination and ethnic cleansing in Yugoslavia, „American Ethnologist” 1996, vol. 23, no. 4, p. 783-801.

Hudson K., Breaking the South Slav dream: the rise and fall of Yugoslavia, London 2003.

Jovanović S., The Creation and breakup of Yugoslavia and Czechoslovakia: developing polypeitharchic history, Belgrade 2017.

Jović V., Psihoanalitički osvrt na pitanja kompenzacije prisilno mobilisanih izbeglica, in. Posledice prinudne mobilizacije izbeglica 1995. godine, eds. G. Opačić, V. Jović, B. Radović, G. Knežević, Beograd 2006, p. 105-130.

Knezevic M., Reporting rights? A look at threats to journalism in the former Yugoslavia since the Balkans wars, „Index on Censorship” 2015, vol. 44, no. 3, p. 52-55.

Kohn E., Rape as a weapon of war: women's human rights during the dissolution of Yugoslavia, „Golden Gate UL Rev." 1994, no. 24, p. 199.

Kolarić J., Dosije: prisilna mobilizacija izbeglica, Beograd 2019.

Korac M., Gender, conflict and peace-building: lessons from the conflict in the former Yugoslavia, „Women's Studies International Forum” 2006, vol. 29, no. 5, p. 510- 520.

Lindsey R., From atrocity to data: historiographies of rape in former Yugoslavia and the gendering of genocide, „Patterns of Prejudice” 2002, vol. 36, no. 4, p. 59-78.

Lischer S., Kenyon S., Militarized refugee populations: humanitarian challenges in the former Yugoslavia, in: The Rosemarie Rogers Working Paper Series, 1999, no. 5.

López-Barajas Aguilar J., Y llegó la barbarie. Nacionalismo y juegos de poder en la destrucción de Yugoslavia, "Cuadernos de Historia Contemporánea" 2016, no. 38, p. 474-475.

Lucarelli S., Europe and the breakup of Yugoslavia: a political failure in search of a scholarly explanation, Leiden 2000.

Magaš B., The destruction of Yugoslavia: tracking the break-up 1980-92, London-New York 1993.

Mandelbaum M., A perfect failure: NATO's war against Yugoslavia, "Foreign Affairs" 1999, vol. 2-8.

Massey G., Hodson R., Sekulić D., Ethnic enclaves and intolerance: The case of Yugoslavia, "Social Forces" 1999, vol. 78, no. 2, p. 669-693.

Mihajlov M., Can Yugoslavia survive?, "Journal of democracy" 1991, vol. 2, no. 2, p. 79-91.

Mitić M., Vuković S., Psihološki profil prisilno mobilisanih, in: Posledice prinudne mobilizacije izbeglica 1995. godine, eds. G. Opačić, V. Jović, B. Radović, G. Knežević, Beograd 2006, p. 79.

Naimark N., Case H., Yugoslavia and its historians: understanding the Balkan wars of the 1990s, Stanford 2003.

Oberschall A., The manipulation of ethnicity: from ethnic cooperation to violence and war in Yugoslavia, „Ethnic and racial studies” 2000, vol. 23, no. 6, p. 982-1001.

Opačić G., Jović V., Knežević G., Tortura ili obuka: vrste mučenja u grupi izbeglica prisilno mobilisanih u Srbiji u toku 1995. godine, in: Posledice prinudne mobilizacije izbeglica 1995. godine, eds. G. Opačić, V. Jović, B. Radović, G. Knežević, Beograd 2006, p. 59.

Orel B., The Theatre exchange between Slovenia and the republics of former Yugoslavia in the 1990s, in: Theatre in the Context of the Yugoslav Wars, New York 2018, p. 227-242.

Pavković A., The fragmentation of Yugoslavia: nationalism and war in the Balkans, New York 2000.

Perks R., Thomson A., The oral history reader, Abingdon 2015.

Powers G., Religion, conflict and prospects for reconciliation in Bosnia, Croatia and Yugoslavia, „Journal of International Affairs" 1996, vol. 50, p. 221-252.

Rabrenovic G., The dissolution of Yugoslavia: ethnicity, nationalism and exclusionary communities, „Dialectical anthropology” 1997, vol. 22, no. 1, p. 95-101. 
Radović B., „Oni” su ih htjeli, a „on” nije: o kontekstu, organizaciji i sprovođenju prinudne mobilizacije izbeglica u Srbiji 1995. godine, in: Posledice prinudne mobilizacije izbeglica 1995. godine, eds. G. Opačić, V. Jović, B. Radović, G. Knežević, Beograd 2006, p. 11.

Ramet S., Thinking about Yugoslavia: scholarly debates about the Yugoslav breakup and the wars in Bosnia and Kosovo: Cambridge 2005.

Ramet S, Pavlakovic V., Serbia since 1989: politics and society under Milosevic and after. Washington 2007, http://public.eblib.com/choice/publicfullrecord.aspx? $\mathrm{p}=3444386$ [access: 30.09 .2020 ].

Schabas W., The UN international criminal tribunals: the former Yugoslavia, Rwanda and Sierra Leone: Cambridge 2006.

\section{Press:}

Alternativna informativna mreža (AIM). Jovanović V., Jeftine glave, 10.03.1994, http://aimpress.ch/dyn/ pubs/archive/data/199403/40310-003-pubs-pod.htm [access: 27.11.2020].

Alternativna informativna mreža (AIM). Lučić Čavić M., Pregled štampe, 31.01.1994, http://www.aim press.ch/dyn/pubs/archive/data/199401/40131-003-pubs-beo.htm [access: 27.11.2020].

Alternativna informativna mreža (AIM). Švarm F., Hajka na Krajišnike, 18.06.1995, http://www.aim press.ch/dyn/pubs/archive/data/199506/50618-001-pubs-beo.htm [access: 27.11.2020].

„Danas”. Ministarstvo odbrane: Pavle Bulatović ubijen pre 20 godina a rezultata istrage ni danas nema, „Danas”, 07.02.2020, https://www.danas.rs/drustvo/ministarstvo-odbrane-pavle-bulatovic-ubijenpre-20-godina-a-rezultata-istrage-ni-danas-nema/ [access: 27.11.2020].

„Deutsche Welle”. RujevićN., Konačno istina o Arkanovom ubistvu?, „Deutsche Welle”, 10.02.2020, https:// www.dw.com/sr/kona\%C4\%8Dno-istina-o-arkanovom-ubistvu/a-52321421 [access: 27.11.2020].

Kurir.rs. Ceca nacionale sa Jovanon u ludom provodu! Srpska majka u transu na proslavi Bajrama kod Harisa Džinovića (video), https://www.kurir.rs/stars/3470129/ceca-i-jovana-u-ludom-nocnomprovodu-pevacica-sve-snimala-a-oni-su-im-pravili-drustvo-lom-video [access: 27.11.2020].

„Naša borba”. Lov na ljude na novosadski način: e, sad neću ni kako „oću“, „Naša borba“, 29.06.1995, p. 13.

„Naša borba”. Milicija odvodila mladiće sa maturske večeri, „Naša borba”, 15.06.1995.

„Naša borba”. Milicija 'češlja'Studentski grad., „Naša borba”, 15.06.1995.

„Naša borba”. Mobilizacija krajišnika u Srbiji se nastavlja: Milicija ‘češlja’ Studentski grad, „Naša borba", 15.06.1995.

„Naša borba”. Mobilizacija u Srbiji između politike i bezakonja: lov na topovsko meso, „Naša borba“, 24 25.06.1995, p. V.

„Naša borba”. Racija u beogradskom noćnom klubu „Havana “: upad u „raj za Bosance“, „Naša borba“, 27.06.1995, p. 2.

Sputniknews, Svakog četvrtka na Sputnjiku: Momir Bulatović - bez distance [Сваког четвртка на Спутьику: Момир Булатовић - без дистанце], 08.08.2016, https://rs.sputniknews.com/ komentari/201708081112213294-Momir-bulatovic-kolumne-1/ [access: 27.11.2020].

„Svet\&scandal”. Ceca Ražnatović o svojim nadimcima: "Srpska majka” mi je omiljen!, „Svet\&scandal”, 06.02.2016, https://www.svet.rs/vesti/estrada/ceca-raznatovic-o-svojim-nadimcima-srpska-majkami-je-omiljen [access: 27.11.2020].

„Večernje novosti”. Kontrola, a ne mobilizacija, „Večernje novosti”, 25.06.1995.

"Vreme". Milošević M., Švarm F., Nikolić Z., Brajović V., Milovanović V., Ubistvo ministra vojnog, "Vreme", 12.02.2000, https://www.vreme.com/arhiva_html/475/03.html [access: 27.11.2020]. 